\title{
ECONOMIC POTENTIAL OF RECREATIONAL FISHING FOR SUSTAINABLE DEVELOPMENT OF COASTAL AREA
}

\author{
Tamara Grizane $^{1}$, Dr.oec.; Aija Sannikova², Dr.oec.; Lìga Jankova3 ${ }^{2}$ Dr. oec; Inguna \\ Jurgelane ${ }^{4}$, Dr.oec. \\ ${ }^{1}$ Turiba University; ${ }^{2}$ University of Economics and Culture; ${ }^{3}$ Latvia University of Life Sciences and Technologies; \\ ${ }^{4}$ Riga Technical University
}

\begin{abstract}
The current economic crisis caused by both the coronavirus disease and the global prevention measures, will have significant negative impact on the tourism sector. Some of the negative consequences possibly can be averted by increasing return from tourism industry. One of the opportunities is to develop the recreational fishing tourism. Until now the economic potential of the recreational fishing for ensuring sustainable development of Kurzeme coastal area was not acknowledged. The aim of the research was to determine the residents and non-residents coastal recreational anglers at the Baltic Sea coast of Kurzeme region and their total expenses. Through use of primary data acquired in recreation fishing environment the demographic data and habitual data of resident and non-resident anglers were analysed and compared to those of different regions in the EU and Australia. The calculated result is EUR 4,558 698 and that underlines the assumption on the economic potential of recreational fishing in the Baltic Sea coast of Kurzeme Region.
\end{abstract}

Key words: sustainable; coastal area; recreational fishing tourism.

JEL code: R11; Z32

\section{Introduction}

It is estimate that in the EU there are 8.7 to 9 mil. recreation fishing tourists that constitute $1.6 \%$ of EU citizens (European Parliament, 2018). For certain countries there are statistical data on the number of coastal anglers. In Germany, there are 165 000, in Poland 80000 , while in the Baltic countries there is no clear data. In some sources it is stated that in Latvia there are 41000 to 100000 to some extent even 120000 anglers, however the real number is not known, which is a real obstacle for carrying out evidence based research work (CCB, 2017: 6; Hyder K. et al., 2017).

The coastal fishermen in the EU are angling an estimated 77 mil. days per year, bringing into the economy about 10.5 bil. Euro, while directing part of the money towards purposes for a sustainable development of the coastal areas (HELCOM, 2015; Spahn, 2016). Since the tourism in Latvia in 2019 constituted around $4.3 \%$ of GDP, the current economic crisis caused by both the coronavirus disease and the global prevention measures, will have significant negative impact on the tourism sector. This situation requires urgent reaction to work out appropriate countermeasures. It is ever more unfortunate that in 2019, despite the number of tourists in Latvia rising, the forecasted financial return did not meet the expectations. This unclaimed revenue would have been ever more important in nowadays situation to avert the impact of the crisis (Aleksejenko R., 2019; Luka-Ruskulova M. and Kalnina I., 2019).

One of the possibilities for increasing of number of tourists and the revenue is the increase of variety of tourism services, which is possible through further development of the tourism industry recreational fishing tourism. Recreational fishing takes place mainly with the aim of hobby fishing and for personal consumption, and does not involve selling. The fact that this type of recreational activity has a high potential has been acknowledged by Sweden, Finland, Estonia, Poland, Lithuania and Latvia through increased efforts to study the potential of recreational fishing tourism around the Baltic Sea area. There is a high potential for Kurzeme region in Latvia to be developed into quality destination for fishing tourism, while helping the cause of sustainable development for coastal area (Kurzemes planosanas regions, 2019). This goes hand in hand with the opinion of many authors, stating that the current EU policy which was aimed mainly at limiting the fishing activity in the Baltic 
Sea, has deteriorated and endangered the livelihood of the coastal area populations. These policies have even been contrary to neoliberal approach: among the most of the Baltic Sea coastal areas populations in the past 20 years an increase in unemployment and reduction of the relative income has been observed (Loizou E. et.al, 2014).

In the Latvian scientific literature, the topic of coastal fishing and its contribution the coastal tourism has not been throughout researched. Individual papers cover the topics of coastal industrial fishing, or impact analysis of the investments in infrastructure and protection of cultural heritage (Baltic Consulting, 2011; Benga, E., 2014). Other publications in Latvia and Europe are aimed at investigating the connection between the investment by the European Fishery Fund (EFF) and European Maritime and Fisheries Fund (EMFF) development of coastal area (Puzulis, A. \& Veveris, A., 2019). There are very few articles on the recreational fishing tourism (European Parliament, 2018) and even fewer papers are about the coastal fishing tourism covering the issue of sustainability and impacts on climate change (Grizane T., et al., 2019; Grizane T., Jurgelane-Kaldava I., 2019; Grizane T., Blumberga, D., 2020).

The first countrywide survey of recreational fisherman was conveyed in 2018 by the Latvian Rural Advisory and Training Centre (LRATC) and initiated by the Latvian Ministry of Agriculture (LMA) (Zemkopibas ministrija, 2018). The survey represented the whole state, while Kurzeme region accounted for $n=141$ fishermen responses. The survey was carried out on the visidati.lv online webplatform. One of the main aims of the LRATC was to estimate the demographic indicators and expenses of the anglers (Zemkopibas ministrija, 2018).

Meanwhle the research project RETROUT Nr.R065 which was initiated by the Kurzeme planning region is the first of its kind research papers (hereafter KPR_R research) on coastal fishing tourism covering specifically the Baltic Sea coastal area of Kurzeme region.

The Research goal of this research: Determination of the resident and non-resident coastal recreational fishermen and determination of total expenses. Research tasks: 1) to determine the demographic indicators of fishing tourism; 2) to calculate the expenses of recreational fishermen in a given area; 3 ) to compare the results with those of similar research in Europe and World. Research methods: monographic, comparison, abstract-logical method, synthesis and analysis, induction and deduction; in processing the primary data, the authors used statistic data analysis - descriptive statistics. Research sources and materials: information provided the LRATC, LMA, LCSB, documents, statistics and research studies done in Latvia and international organizations.

\section{Research results and discussion}

\section{Case study site and study approach}

The Eurostat (2017) defines the coastal territories as municipalities, that border sea or which are located within a $10 \mathrm{~km}$ distance from the coastline. Meanwhile the task by the contracting entity of the KPR_R research was to include a wider area. As a result, the survey of fishermen was carried out both on the Western Baltic Sea coastline of Kurzeme region within an area from Papes up to Irbe river delta, and in-lands stretching out to the Pape, Liepaja, Durbe, Tasu and Usmas lakes.

The concentration of anglers is dependent on the climate factors: strength of wind, temperature, water flows, sea weed density, existence of fish in the given area and the time. The scope of the survey population was limited by both the stated climate factors, and the availability of the surveyees (which were fishing from the sea coast, lakeside or riverside), given task and available resources. Therefore, a limited quota population of $(n=65)$ was assessed. The survey was carried out in 2019 
five days in August and two in September, which were deemed the most appropriate for fishing purposes: on Durbe lake, Pape lake and canal, Usma and Puze lake, at the sea coast: Jurkalne, Jurmalciems, Liepaja, Luzna, Mikeltornis, Ovisi, Pavilosta, Pitrags, Uzava and Ventspils.

The gathering of the data on the habits of the fishermen allowed to determine how many times per year and for how long they are visiting Kurzeme seacoast, while the demographic data allowed to determine the gender, age, place of residence, in order to determine the length of the journey to the fishing destination. The number of missing responses was removed from the calculations.

In order to determine the total costs of the fishing trip, the following formula was used:

$$
\text { TAEX = Average Fish/Trip/year } \times \text { NA } \times \text { Average EUR/TRIP }
$$

Where:

TAEX- total expenses of anglers per year;

NA - number of anglers;

Average Fish/Trip/year - the average number of journeys per year;

Average EUR/Trip - the average expenses of fishing trips per year.

* each target group (residents and non-residents) is calculated separately and the average is calculated.

The expenses of fishing trip were calculated per one day based on the formula:

$$
\text { Average EUR/day }=\text { TAEX/(Average FishDay) }
$$

Where:

Average EUR/day - average daily expenses;

TAEX- total fishing trip related expenses per year;

Average FishDay - the average number fishing days per year.

For the comparison of data acquired within the KPR_R research, the data from 2017 fishermen survey carried out by the Latvian Rural Advisory and Training Centre (LRATC), as well as information from research from Europe and Australia, was used. The differences in the research approach were taken into account, refined and recalculated in monetary harmonized data.

\section{Demography and habits of fishermen, their comparison}

In the KPR_R research it was determined, that the average age of respondents was 45.9 years, minimum age was 12 , while the maximum - 76 years. The Table 1 indicates that the survey population is dominated by males and residents. The proportion of female and male anglers was 1:15. Comparatively, in Sweden this proportion is more harmonized with ratio of $1: 2$ (Sveriges officiella statistic, 2018).

Demographical data of fishermen

\begin{tabular}{|l|c|c|}
\hline Fisherman determining variable & Number & Distribution in percentage (\%) \\
\hline Gemale & 4 & 6.2 \\
\hline Male & 61 & 93.8 \\
\hline \multicolumn{3}{|c|}{ Nationality } \\
\hline Resident & 57 & 87.7 \\
\hline Non-resident & 8 & 12.3 \\
\hline \multicolumn{3}{|c|}{ Age (years) } \\
\hline $\mathbf{1 5}$ & 2 & 3.1 \\
\hline $\mathbf{1 6 - 3 0}$ & 8 & 12.3 \\
\hline $\mathbf{3 1 - 6 4}$ & 46 & 70.8 \\
\hline $\mathbf{6 5}>$ & 9 & 13.8 \\
\hline
\end{tabular}


When comparing the age group distribution of anglers with the data from LRATC research, it was determined that the number of youth under 15 years was by $2.3 \%$ greater, in the age group from 31 to 64 the proportion was similar, but the number of fishermen in the age category 16-30 years was by $13.17 \%$ fewer; meanwhile in the age category $65+$ the research of the authors of this paper show greater difference $-12.38 \%$ which could be related to the fact that in the survey by LRTAC there were fewer respondents of senior age due to digital skills gap. Therefore, authors assume that the results of the 2019 survey show a more realistic depiction of reality in the field of fishing tourism. Additionally, in the 2019 survey the senior category was extracted of the dataset, because they are exempt from fishing card costs.

The local active anglers, mainly from Liepaja and Ventspils cities, annually visit the fishing destinations in the range from 40 to 180 times, thus the total number of days spent on average is 59.79 days, but when the 'daily anglers' are excluded from the dataset, the number of total days is 32.66 days. Occasionally it reaches the national average of 37.30 days per year (Hyder K. et al, 2017). When comparing with other Baltic Sea countries, in Finland on average it is 27.3 , Norway 21.1, Denmark 21, Sweden 12.1, thus the mean number of fishing days is greater, whoever it should be accounted for the difference in the categories of fishermen (Toivonen A-L. et al., 2000).

The research by the LRATC calculated the number of fishermen from Riga at $15.5 \%$ fewer. The departure location of the rest of respondents is in vicinity of 18 towns of Latvia, as well as from four towns in Lithuania (Kauna, Klaipeda, Telsiai and Siauliai) and two towns in Germany (Hanover and Munich), thereby even more wider territory is included, mainly representing urban areas. This coincidence should be further examined in the further research. This could possibly be attributed to the household income disparity between the rural and urban areas, because the travel to the Kurzeme western coastline requires significant investments.

\section{Expenditures of recreational fishermen}

Travel costs constitute a significant part of the expenditures of the fishermen, most significantly impacting the non-resident fishermen (Fig. 1), where their expenses are by EUR 77.63 higher than those of residents. All of the Kurzeme coastline trips included use of car as the choice of transport and the fuel costs constituted $14.57 \%$ of the total expenses for anglers residents, while $46.6 \%$ for anglers non-respondents, or on the average $30.59 \%$. In Denmark, the travel costs of the anglers were lower - just $27 \%$ of the travel expenses, in Finland - $35 \%$, Sweden $-39 \%$ (Toivonen A-L. et al., 2000).

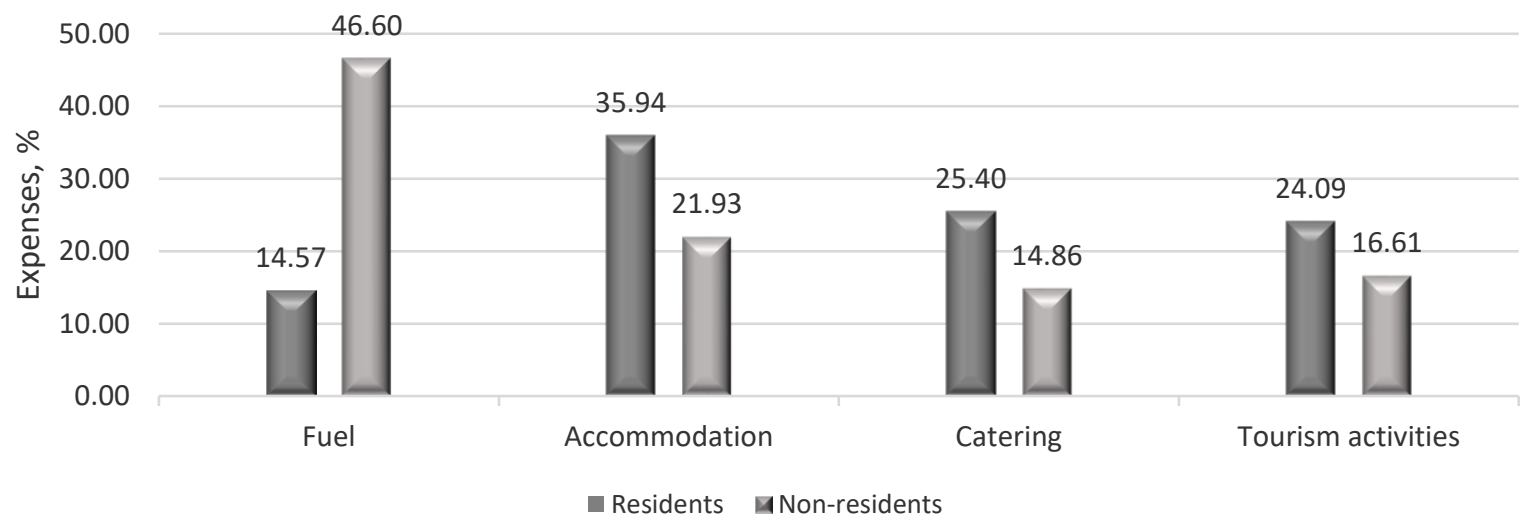

Source: author's calculations based on results of the survey

Fig. 1. The average expenses of residents and non-residents per single trip, \% 
However, the anglers residents (Fig. 1) similarly as in the LRATC research spent the largest sum for accommodation services, the difference was just $3.24 \%$. The catering costs were by $26.18 \%$ larger for anglers residents, while similar results are seen in their expenses on tourism activities both indicators were by $18.38 \%$ larger for anglers non-residents. On average the expenses for angler resident (Table 2) per trip were by EUR 103.2 lesser for non-residents, which is connected with a larger fuel consumption during the trip and thus larger expenses for accommodation services.

The total expenses for the fishing gear in the destination and in home for residents (Table 2 ) is by EUR 207 smaller than those of non-residents, while the price of the fishing gear purchased at home on average is EUR 1649. It should be noted that only $41.54 \%$ of respondents indicated their expenses for fishing gear at home. Therefore, it is difficult to calculate representable data on the true costs. In other research it was determined that the overall expenses for fishing gear can differ significantly.

In Poland for the fishing gear on average EUR 190 is spent; in Denmark - even EUR 1000 per year in Germany - EUR 783, while in Lithuania on average - EUR 375 (The Interreg South Baltic..., 2018).

The costs related to boats and their transportation total a significant share of expenses (Table 2) altogether EUR 4668, while only $22 \%$ of respondents own a boat, while two had borrowed the utilities for their transportation from their friends, only $6.5 \%$ had rented the boat. However, in Australia $65.14 \%$ of fishermen have boats and their total expenses with the additional equipment (engine, trailer) on average are relatively lower by EUR 2596.21 (European Central bank, 2018; McLeod P., Lindner R., 2018).

The KPR_R research indicated that the fishing outfit is important for just $22 \%$ of anglers (Tab. 2) and that on average they spend around 113 EUR, while non-respondents spend in the range from EUR 90 to 135.

The foreign experience shows that when comparing the fishing licence prices, in the period (19982016), a significant difference was observed between Estonia, Latvia and Lithuania, Poland, Finland and Sweden: the costs of daily licence rose from EUR 1 to 8.11, weekly licence from EUR 3 to 20.45, while the annual licence from EUR 14.23 to EUR 45 and EUR 33.80 in Sweden and Finland (KPR, 2019). The KPR_R research operates with the data on the annual fishing licence, which is two times less expensive than that in Sweden and Finland. 


\section{Average annual and per trip costs of coastline anglers} of Kurzeme coastline, EUR

\begin{tabular}{|c|c|c|c|c|}
\hline Expenditure category & $\begin{array}{c}\text { Total expenses of } \\
\text { anglers residents in } \\
\text { each category (year) } \\
\text { (EUR) }\end{array}$ & $\begin{array}{l}\text { Total expenses of } \\
\text { angler non-residents in } \\
\text { each category (year) } \\
\text { (EUR) }\end{array}$ & $\begin{array}{l}\text { Average } \\
\text { expenses of } \\
\text { angler } \\
\text { residents } \\
\text { (per trip*) } \\
\text { (EUR) }\end{array}$ & $\begin{array}{l}\text { Average expenses of } \\
\text { angler non-residents } \\
\text { (per trip*) (EUR) }\end{array}$ \\
\hline \multicolumn{5}{|c|}{ Direct expenses } \\
\hline Fuel & 37457.02 & 10913.65 & 13.47 & 91.18 \\
\hline Accommodation & 92432.91 & 5137.52 & 33.24 & 42.92 \\
\hline Catering & 65320.37 & 3480.88 & 23.49 & 29.08 \\
\hline Entertainment & 61955.63 & 3890.25 & 22.28 & 32.50 \\
\hline Total: & 257165.92 & 23422.3 & 92.48 & 195.68 \\
\hline \multicolumn{5}{|c|}{ In-direct expenses } \\
\hline Fishing gear (in destination) & 227565,57 & 15810.8 & 5.41 & 30.45 \\
\hline Fishing gear (at home) & 1472252,38 & 0 & 42.90 & 0.00 \\
\hline Boat & 1707355,27 & 0 & 102.87 & 0.00 \\
\hline Boat trailer & 293276,06 & 0 & 18.56 & 0.00 \\
\hline Fishing clothing & 494066,63 & 4089 & 10.91 & 8.25 \\
\hline Licence and card & 32910,02 & 1105,67 & 0.69 & 1.34 \\
\hline Additional expenses & 28864.43 & 813.96 & 0.27 & 0.50 \\
\hline In total: & 4256290.357 & 21819.43 & 181.60 & 40.54 \\
\hline Total: & 4513456.277 & 45241.73 & 274.08 & 236.22 \\
\hline
\end{tabular}

Source: author's calculations based on results of the survey

The additional costs do not contribute to significant part of expenses in the total expenditures per fishing trip, however that impact the direct and indirect fishing costs. The direct costs include the costs for products and services which are directly necessary for the fishing purpose within the given fishing trip, while the indirect costs are related to the expenses on long-term investments. The average fishing costs for residents (Tab. 2) is about EUR 274, while for non-residents EUR 236. In comparison, according to Hyder et al. (2017), the local expenditures of local residents for Latvia have been calculated at EUR 243, for Estonia - EUR 276; Lithuania - EUR 277; Poland - EUR 257; Finland - EUR 350; Sweden - EUR 399 and Germany - EUR 677. However, Arlinghaus (2006) indicated that the German anglers spend on average EUR 920 for their hobby per year (Arlinghaus R., 2006). Therefore, the results are close to the expenses of the fishermen in the Baltic countries. However, comparisons with results of this research should be interpreted carefully, because the respondent choice criteria, sample, context and question structure is different, also the expenditures per year are demonstrated in constant prices and are different to different countries. The data clearly illustrate that the expenses of fishermen arising from the hobby and travel transport related expenses at the Kurzeme coastline at the Baltic Sea can have a significant impact on the sustainable development for coastal area, based on the assumption that according to the economic sustainability-approach, the aggregate human utility does not tend to decline over time (Asheim, 2007).

It should be noted that the coastal area is a specific territory and that tourism, including the fishing tourism, can have a significant positive impact for the local economy. The socio-economic and environmental integration process, when tourism blooms, can help develop and upkeep the coastal territories in such a way and scale so that it would be viable and would not alter the environment, while promoting the processes for more successful development and welfare.

\section{Conclusions, proposals, recommendations}

1) The KPR_R research is the first of such kind in Latvia and the only one focusing on the fishing tourism in the Baltic Sea Kurzeme coastline, which has been carried out on-field, unlike the LRATC research, which took place only in online environment. The following demographical and habitual 
indicators were identified: average age of an angler - 45.9 years, number of senior anglers greater than $12 \%$; total number of days spent on fishing 33 days; by $16 \%$ fewer fishermen from Riga; geographical origin - Latvia, Lithuania, Germany.

2) Largest expenses for anglers-residents are spent on accommodation $36 \%$, catering $25 \%$ and touristic activities $24 \%$, but largest expenses for angler's non-residents on fuel $47 \%$. The average expenses for residents are around EUR 274 and for non-residents EUR 236, which differs most significantly from Sweden and Germany.

3) EUR 4,558 698 is the financial illustration of the possible positive impact on the sustainable development and coastal area development at the Baltic Sea coastal area of Kurzeme region.

4) In the further research it is necessary to continue in-depth analysis of the coastal area fishing tourism potential, to monitor, accumulate statistical database, based on the real-world environment.

\section{Acknowledgement}

The authors are thankful to the project marketing consultant of the Kurzeme Planning Region (KPR) and to The Institute of Social, Economic and Humanities Research of Vidzeme University of Applied Sciences (ViA HESPI) for permission to use the primary data acquired within the RETROUT Nr. R065 project.

\section{Bibliography}

1. Arlinghaus, R. (2006). Der unterschatzte Angler. Zukunftsperspektiven fur die Angelfischerei in Deutschland (Deutsch) (Underrated angler. Fishing prospects in Germany) Stuttgart: Kosmos; Auflage: 1. Aufl. (August 2006), 168 Seiten.

2. Asheim, GB. (2007). Justifying, Characterizing and Indicating Sustainability, Springer: Dordrecht, the Netherlands, p.269.

3. Baltic Consulting. (2011). Ricibas programmas Eiropas Zivsaimniecības Fonda atbalsta ieviesanai Latvija 2007. - 2013. gadam Vidus termina (Interim) novērtējums. Zinojums. (Action Programe of Implementation of the European Fisheries Fund Support in Latvia 2007-2013. Interim assessment report).

4. Bartlomiejski, R. (2011). Fisheries Local Action Groups: A New Theme for Researching Maritime Communities Roczniki Socjologii Morskiej. Annuals of Marine Sociology, XX.

5. Benga, E. (2014). Zvejniecibas attistiba Baltijas juras un Rigas juras lica piekrastes josla (piekrastes zveja). Atskaite. (Fishing Development in the Coastal Zone of the Baltic Sea and the Gulf of Riga (Coastal Fishing. Report)) LVAEI.

6. Coalition Clean Baltic 2017 (CCB) (2017). Recreational Fishing in the Baltic Sea Region. Retrieved: https://ccb.se/wp-content/uploads/2018/02/ccb_recreational_fishing.pdf Access: 14.03.2020.

7. European Central Bank (2018). Converting Australian Dollars into Euros in 01.10.2018 Retrieved: https://www.ecb.europa.eu/stats/policy_and_exchange_rates/euro_reference_exchange_rates/html/eurofxr ef-graph-aud.en.html Access: 24.03.2020.

8. European Parliament (25.5.2018) REPORT on the State of Play of Recreational Fisheries in the European Committee on Fisheries (2017/2120(INI)) (A8-0191/2018) Available: https://www.europarl.europa.eu/doceo/document/A-8-2018-0191_EN.html Access: 14.01.2020.

9. European Parliament, Atputas zvejas stavoklis Eiropas Savieniba. (State of Play of Recreational Fisheries in the EU). (A8-0191/2018). (2018) Retrieved: http: //www.europarl.europa.eu/doceo/document/TA-8-20180243_LV.html. Access: 22.02.2020.

10. Eurostat (2017). Definition of Coastal Region. Retrieved: https://ec.europa.eu/eurostat/statisticsexplained/index.php/Glossary: Coastal_region. Retrieved: https://ec.europa.eu/eurostat/statisticsexplained/index.php?title=Territorial_typologies_manual__coastal_regions\#Classes_for_the_typology_and_their_conditions. Access: 14.01.2020.

11. Grizane, T., Blumberga, D. 2020. Recreation Fishing Impact to Climate Changes. Case of Latvia. Environmental and Climate Technologies, 2020.

12. Grizane, T., Gusca, J., Sannikova, A., Jurgelane-Kaldava, I. (2019). Emissions of Carbon Dioxide (CO2) and Growth the Tourism Industry: Case study of Latvia. In: Proceedings of the 2019 International Conference Economic Science of Rural Development. New Dimensions in the Development of Society. No. 52, pp. 347354. DOI: $10.22616 / E S R D .2019 .141$

13. Grizane, T., Jurgelane-Kaldava, I. (2019). Tourist Transportation Generated Carbon Dioxide (CO2) Emissions in Latvia. Environmental and Climate Technologies, 2019, Vol. 23, No. 3, 274.-292. pp. ISSN 1691-5208. eISSN 2255-8837. DOI: $10.2478 /$ rtuect-2019-0095 
14. Hyder, K. et al. (2017). Recreational Sea Fishing in Europe in a Global Context - Participation Rates, Fishing Effort, Expenditure, and Implications McLeod P., Lindner R., (2018). Economic Dimension of Recreational Fishing in Western Australia. Research Report for the Recreational Fishing Initiatives Fund. P. 83. for monitoring and assessment. Fish and Fisheries, 2017; Vol., pp1-19. Retrieved: https://onlinelibrary.wiley.com/doi/full/10.1111/faf.12251. DOI: 10.1111/faf.12251 Access: 14.01.2020.

15. Phillipson, J., Symes, D. (2015). Finding a Middle Way to Develop Europe's Fisheries Dependent Areas: The Role of Fisheries Local Action Groups. Sociologia Ruralis, Volume 55 Issue 3, pp.343-359. DOI: 10.1111/soru.12098

16. Puzulis, A., Veveris, A. (2019). Role of the European Fishery Fund Support in the Development of the Latvian Coastal Areas. Research for Rural development 2019, Volume 2., pp.111-117. DOI: 10.22616/rrd.25.2019.057

17. Raimonds Aleksejenko (LV), Deputy State Secretary, Ministry of Economics. Latvia Tourism Vision 2020+ (2019). Retrieved: https://www.youtube.com/watch?v=aDYzyGTIFf8 Access: 13.01.2020.

18. Sveriges officiella statistic (2018). Statistsika Meddelanden JO 57 1910. Fritidsfeske I Sverige 2018. (Recreational Fishing in Sweden 2018) Retrieved: https://www.scb.se/contentassets/cfbd2f4a6c8e4fb9b1f9293609b00c59/jo1104_2018a01_sm_jo57sm1901. pdf Access: 23.03.2020.

19. Symes, D., Phillipson, J. (2009). Whatever Became of Social Objectives in Fisheries Policy? Fisheries Research, Volume 95 Issue 1, pp.1-5. DOI: 10.1016/j.fishres.2008.08.001.

20. Kurzeme planning region (KPR) (2019). Zinojums par makskeresanas turisma lomu ekonomika projekta partnervalstis: Zviedrija, Somija, Polija, Lietuva, Igaunija, Latvija. (Report on the Role of Recreation Fishing Tourism in the Economy Project Partner Countries: Sweden, Finland, Poland, Lithuania, Estonia, Latvia) HESPI, p.40.

21. Kurzeme Planning Region. In project RETROUT a plan for Baltic Sea Coastline as a sport and recreation fishing destination is being planned (2019). Retrieved: https://www.kurzemesregions.lv/projekta-retrout-tiekizstradats-plans-baltijas-juras-piekrastes-ka-sporta-un-atputas-makskeresanas-turisma-galamerkaveidosanai/ Access: 13.10.2019.

22. Loizou, E., Chatzitheodoridis, F., Michailidis, A., Polymeros, K., Mattas K. (2014). Sustainable Development of Rural Coastal Areas: Impacts of a New Fisheries Policy. Land Use Policy. Volume 38, pp. 41-47. DOI: 10.1016/j.landusepol.2013.10.017

23. Luka-Ruskulova, M., Kalnina, I. Latvia Tourism Vision 2020+. Turisma politika 2021-2023. (Tourism Policy 2021-2023.) (2019). Retrieved: https://www.Ips.Iv/uploads/docs_module/Latvijas\%20t\%C5\%ABrisma\%20v\%C4\%ABzija\%202020+.pdf Access: 13.10 .2019 .

24. Symes, D., Phillipson, J., Salmi, P. (2015). Europe's Coastal Fisheries: Instability and the Impacts of Fisheries Policy. Sociologia Ruralis, 55(3), 245-257. DOI: 10.1111/soru.12096

25. The Interreg South Baltic project CATCH (2018). The CATCH Angler Survey Report (January 2018). Retrieved: http://catch-southbaltic.eu/wp-content/uploads/2018/02/CATCH-ANGLER-SURVEY-REPORT.pdf Access: 14.03.2020.

26. Toivonen, A-L., Appelblad, H., Bengtsson, B., Geertz-Hansen, P., Gudbergsson, G., Kristofersson, D., Kyrkjebo, H., Navrud, S., Roth, E., Tuunainen, P., Weissglas, G. (2000). Economic Value of Recreational Fisheries in the Nordic Countries. Nordic Council of Ministers, Copenhagen 2000, p.71.

27. Walle, G. (2017). Assessment of Fisheries Local Action groups support to Small Scale Coastal fisheries in Europe. Technical Report. DOI: 10.13140/RG.2.2.21228.05763.

28. Ministry of Agriculture 2018. Results of fishermen surveys, year 2017. (angl) (2018). Retrieved: https://www.zm.gov.Iv/public/ck/files/Rezultati(1).pdf Access: 13.03.2020. 